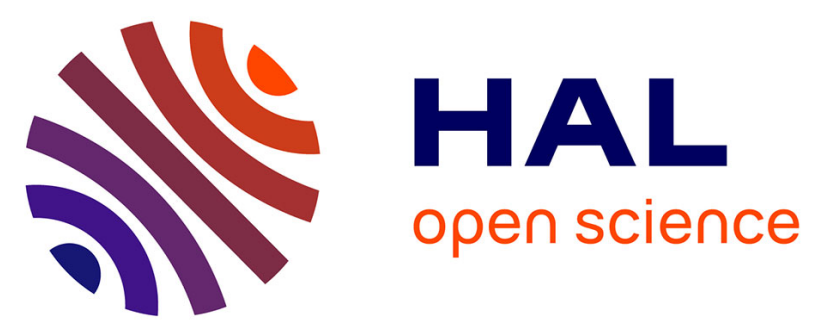

\title{
Alterations in alpha5* nicotinic acetylcholine receptors result in midbrain- and hippocampus-dependent behavioural and neural impairments.
}

Morgane Besson, Stefania Guiducci, Sylvie Granon, Jean-Philippe Guilloux, Bruno Guiard, Christelle Repérant, Philippe Faure, Stéphanie Pons, Giuseppe Cannazza, Michele Zoli, et al.

\section{To cite this version:}

Morgane Besson, Stefania Guiducci, Sylvie Granon, Jean-Philippe Guilloux, Bruno Guiard, et al.. Alterations in alpha5* nicotinic acetylcholine receptors result in midbrain- and hippocampusdependent behavioural and neural impairments.. Psychopharmacology, 2016, 233 (18), pp.3297-3314. 10.1007/s00213-016-4362-2 . hal-01346030

\section{HAL Id: hal-01346030 \\ https://hal.science/hal-01346030}

Submitted on 17 Feb 2017

HAL is a multi-disciplinary open access archive for the deposit and dissemination of scientific research documents, whether they are published or not. The documents may come from teaching and research institutions in France or abroad, or from public or private research centers.
L'archive ouverte pluridisciplinaire HAL, est destinée au dépôt et à la diffusion de documents scientifiques de niveau recherche, publiés ou non, émanant des établissements d'enseignement et de recherche français ou étrangers, des laboratoires publics ou privés.

\section{(ㅇ)(1) $\$$}

Distributed under a Creative Commons Attribution - NonCommercial - NoDerivatives $\mid 4.0$ 


\section{Alterations in alpha5* Nicotinic Acetylcholine Receptors Result in Midbrain- and Hippocampus-Dependent Neurobehavioural Impairments}

Morgane Besson ${ }^{1}$, Stefania Guiducci ${ }^{2}$, Sylvie Granon ${ }^{3}$, Jean-Philippe Guilloux ${ }^{4}$, Bruno Guiard ${ }^{4}$, Christelle Repérant ${ }^{4}$, Philippe Faure ${ }^{5}$, Stéphanie Pons ${ }^{1}$, Giuseppe Cannazza ${ }^{6}$, Michele Zoli ${ }^{2}$, Alain M. Gardier ${ }^{4}$, Uwe Maskos ${ }^{1}$.

1 Neurobiologie Intégrative des Systèmes Cholinergiques, Département de Neuroscience, CNRS UMR 3571, Institut Pasteur, Paris, 75724 cedex15, France

2 Department of Biomedical, Metabolic and Neural Sciences, Section of Physiology and Neurosciences, University of Modena and Reggio Emilia, Modena, 41121, Italy

3 Neurobiologie de la Prise de Décision, Centre de Neurosciences Paris-Sud, Orsay, 91405, France 4 Neuropharmacologie des troubles anxieux-dépressifs et neurogénèse, Université Paris-Sud XI, Chatenay-Malabry, 91290, France

5 Neurobiologie des processus adaptatifs, Neurophysiologie et Comportement, Université Pierre et Marie Curie, Paris, 75005, France

6 Department of Life Sciences, University of Modena and Reggio Emilia, Modena, 41121, Italy

\section{Corresponding author}

Morgane Besson

Neurobiologie Intégrative des Systèmes Cholinergiques, Département de Neuroscience, CNRS UMR 3571, Institut Pasteur, Paris, 75015, France

Tel : 0033140613777

morgane.besson@pasteur.fr

Acknowledgments: This work was supported by the Institut Pasteur, Centre National de la Recherche Scientifique UMR 3571\& 7102, Agence Nationale pour la Recherche, Fondation pour la Recherche Médicale, Neuropole de Recherche Francilien of Ile de France, National Cancer Institute INCa BIO-SILC programme, Ecole des Neurosciences de Paris, EU FP7 ERANET Neuron NICO-GENE network, LabEx BIOPSY funded by ANR, Italian Ministry of Health RF2009-154961. We thank M. Soudant for lentivirus production, C. Morel for sharing vectorized mice and B. Forget for comments on the work and manuscript.

Conflict of interest: The authors declare no competing financial interests. 


\begin{abstract}
Rationale

Evidence links alterations in $\alpha 5$-containing nicotinic receptors ( $\alpha 5^{*}$-nAChRs) to nicotine addiction. Notably, the rs 16969968 polymorphism found in the human $\alpha 5$ subunit gene ( $\alpha 5 \mathrm{SNP}$ ) increases the risk for heavy smoking and impairs nicotine rewarding properties in mice. Additional work is needed to understand how native and polymorphic $\alpha 5^{*}$-nAChRs may contribute to processes associated with the risk for nicotine addiction.
\end{abstract}

\title{
Objectives
}

We aimed at understanding the contribution of $\alpha 5^{*}$-nAChRs to neurobehavioural endophenotypes like increased responses to novelty and anxiety, known to promote vulnerability to addiction.

\section{Methods}

Behavioural phenotypes were investigated in mice knockout for the $\alpha 5$ gene $\left(\alpha 5^{-/}\right)$and nicotine injections were performed to test the consequences of nicotine exposure on the phenotypes identified. Dopamine and serotonin signaling were assessed using in vivo microdialysis and electrophysiology. We used lentiviral vectors to compare the consequences of re-expressing either the $\alpha 5$ wild-type allele or the $\alpha 5$ SNP in specific brain areas of $\alpha 5^{-/-}$mice.

Results

$\alpha 5^{-/-}$mice did not exhibit high responses to novelty but rather showed decreased novelty-induced rearing behaviour together with high anxiety. Exposure to high doses of nicotine rescues these phenotypes. We identified altered spontaneous and nicotine-elicited serotonin and dopamine activity in $\alpha 5^{-/-}$mice. Finally, re-expression of $\alpha 5$ in the ventral tegmental area and hippocampus rescued rearing and anxiety levels in $\alpha 5^{-/-}$mice, respectively. When expressing the $\alpha 5$ SNP instead, this resulted in a knockout-like phenotype for both behavioural parameters.

\section{Conclusions}

We propose that altered $\alpha 5^{*}$-nAChR cholinergic signalling contributes to emotional/behavioural impairments that may be alleviated by nicotine consumption.

\section{Key words}

Addiction; Nicotine; Vulnerability; Nicotinic receptors; Polymorphism; Mice; Monoamines; Lentiviral vector; Novelty; Anxiety. 


\section{Introduction}

Smoking is the most important cause of preventable mortality and morbidity worldwide (World Health Organization, http://www.who.int/tobacco/statistics/tobacco_atlas/en/). Nicotine, the main reinforcing component in tobacco, acts on the brain via nicotinic acetylcholine receptors (nAChRs) (Changeux 2010). nAChRs are pentameric ion channels composed of different $\alpha$ and $\beta$ subunit combinations with different functional properties. nAChRs containing $\alpha 4$ and $\beta 2$ subunits are predominant in the brain and account for most of the rewarding properties of nicotine (Picciotto and Kenny 2013).

Recently, the $\alpha 5$ subunit was crucially implicated in nicotine addiction. Genome wide association studies reported a strong association between the $C H R N A 3 / A 5 / B 4$ gene cluster, encoding the $\alpha 3$, $\alpha 5$ and $\beta 4$ nicotinic subunits, and predisposition to tobacco smoking (Berrettini and Doyle 2012; Bierut et al. 2008; Saccone et al. 2007). Notably, a non-synonymous single nucleotide polymorphism, changing an aspartic acid into asparagine, was identified in the $\alpha 5$ gene ( $\alpha 5 \mathrm{SNP}$ ), and associated with higher scores of nicotine dependence, heavy smoking, and early onset of smoking (Berrettini and Doyle 2012; Bierut et al. 2008; Grucza et al. 2008; Stevens et al. 2008; Weiss et al. 2008). Strikingly, $\alpha 5$ SNP homozygous carriers have a two-fold higher risk for tobacco addiction than non-carriers (Greenbaum and Lerer 2009; Improgo et al. 2010; Saccone et al. 2007). Although the $\alpha 5$ subunit does not contribute to ligand binding sites, it combines with other $\alpha$ and $\beta$ subunits and influences the receptor properties (Exley et al. 2012; Kuryatov et al. 2008; RamirezLatorre et al. 1996; Tapia et al. 2007), probably through allosteric mechanisms (Taly et al. 2009). Mice knockout for the $\alpha 5$ gene $\left(\alpha 5^{-/-}\right.$mice) are less sensitive to some nicotine effects including seizures and antinociception (Jackson et al. 2010; Salas et al. 2003; Salas et al. 2009). They display decreased somatic nicotine withdrawal syndrome (Salas et al. 2009) and decreased sensitivity to nicotine-induced reward as well as aversion and reward-inhibition at high doses (Fowler et al. 2011; Morel et al. 2014). In vitro studies showed that the $\alpha 5$ SNP causes a partial loss of function of nAChRs containing $\alpha 5\left(\alpha 5^{*}-\mathrm{nAChRs}\right)$, with decreased $\mathrm{Ca}^{2+}$ permeability and current amplitude in response to nicotinic agonists (Bierut et al. 2008; Frahm et al. 2011; Kuryatov et al. 2011). Furthermore, we showed that expressing the $\alpha 5$ SNP instead of wild-type $\alpha 5$ ( $\alpha 5 \mathrm{WT}$ ) in the ventral tegmental area (VTA) causes a rightward shift in the dose response curve to nicotine in both self-administration behaviour and VTA dopamine (DA) neuron activity (Morel et al. 2014).

Altogether, these data show that alterations in $\alpha 5^{*}$-nAChRs result in decreased sensitivity to nicotine. Yet, additional work is needed to understand the role of native and polymorphic $\alpha{ }^{*} *_{-}$ 
nAChRs in the vulnerability to addiction. Only a percentage of individuals exposed to drugs eventually develop addiction. Some personality traits and psychiatric conditions, especially high impulsivity, high novelty/sensation seeking and high anxiety, are strikingly associated with addiction (Belin and Deroche-Gamonet 2012; Gehricke et al. 2007; Kreek et al. 2005). These traits have been identified as predisposing factors conferring vulnerability to drug, including nicotine, abuse in clinical and preclinical studies (Batra et al. 2008; Diergaarde et al. 2008; Falco et al. 2014; Kushner et al. 2012; Redolat et al. 2009; Suto et al. 2001). $\alpha 5^{-/-}$mice did not show a high impulsive phenotype in a 5-choice serial reaction time task (Bailey et al. 2010). However, the role of $\alpha 5^{*}$-nAChRs in, and the impact of the $\alpha 5 \mathrm{SNP}$ on, other neurobehavioural endophenotypes for addiction vulnerability remain unclear. Here we assessed novelty and sensation seeking, modeled as novelty-induced conditioned place preference and locomotor reactivity in novel inescapable environment, respectively (Belin and Deroche-Gamonet 2012), and anxiety in $\alpha 5^{-/-}$mice. We next investigated the consequences of nicotine exposure on the behavioural phenotypes identified. We also assessed, in these mice, spontaneous and nicotine-elicited activities of the DA system, as well the serotonin (5-HT) system for the first time. Finally, we re-expressed, using lentiviral vectors (LVs) (Maskos et al. 2005), either the $\alpha 5 \mathrm{WT}$ or $\alpha 5$ SNP gene in specific brain areas, and compared their impact on $\alpha 5^{-/-}$mice behavioural phenotypes.

\section{Materials and Methods}

\section{Animals}

Experiments were conducted in male C57BL/6J wild-type (WT) mice and constitutive knockout mice lacking the $\alpha 5 \mathrm{nAChR}$ subunit $\left(\alpha 5^{-/-}\right.$mice) (Salas et al. 2003). WT and $\alpha 5^{-/-}$mice were not littermates, however $\alpha 5^{-/-}$mice have been back-crossed to the C57BL/6J strain for more than 20 generations, WT and $\alpha 5^{-/-}$mice were both from Charles River, France, bred in the same life conditions, arrived at the animal facility at the same time and were housed in the same room, and were matched for age and sex. They were used in strict accordance with the Guide for the Care and Use of Laboratory Animals (NIH) and the European Commission regulations for animal use in research (CEE $n^{\circ}$ 86/609), and the IP Animal Care Committee and French Ministry (authorization number 01601.02). The animals were 10 weeks of age at the start of the experiments, housed six per cage with food and water available ad libitum. They were kept under standard conditions (temperature $21 \pm 1{ }^{\circ} \mathrm{C}, 60-65 \%$ relative humidity) on a reversed $12 \mathrm{~h}$ light/dark cycle (light on 7.00 p.m.) All experiments were performed between 9.00 a.m. and 6.30 p.m.

\section{Behavioural testing}

Mice were handled for two days before starting behavioural testing. 
For basal identification of behavioural phenotypes in WT and $\alpha 5^{-/-}$mice, half of the animals were submitted first to the open-field test and 3 days later to the elevated-plus-maze (EPM), while the opposite order was followed for the other half (with equal repartition for both genotypes). The other tests were then conducted in the following order, and with 1 week apart from each other: light-dark box (LDB), novelty preference, novel box exploration for rearing measurement.

For studying the effects of nicotine injections on behavioural phenotypes in WT and $\alpha 5^{-/-}$mice, each mouse received the same dose of nicotine 10 minutes before each test, with 1 week between each test. The order of running of the tests was pseudo-randomized between novelty-induced rearing behaviour, EPM and LDB tasks, so that each testing sequence was represented in an equal number of mice (for both genotypes). Locomotor activity in the open-field was examined last.

For studying the effects of $\alpha 5$ gene re-expression on behavioural phenotypes in $\alpha 5^{-/-}$mice, tests were conducted in the following order, and with 1 week apart from each other: novel box exploration for rearing measurement, EPM, LDB.

Novelty-induced locomotor and exploratory activity. Locomotor reactivity to novelty (ambulation, i.e. horizontal activity) was measured as the total distance travelled in an unfamiliar 1-m-diameter circular open-field. The open-field was virtually divided into a central $(65 \mathrm{~cm})$ and a peripheral (35 $\mathrm{cm})$ zone to further measure the instantaneous velocity divided into two categories: activity (A, > $8.75 \mathrm{~cm} / \mathrm{sec}$ ) and inactivity (I, $<8.75 \mathrm{~cm} / \mathrm{sec}$ ). Different states were thus observed: activity or inactivity in the central zone (CA or $\mathrm{CI}$ ), activity or inactivity in the peripheral zone (PA or PI). Total distance moved; $\%$ of time spent in the periphery; \% time spent in inactivity; \%PI or \%CI; \% PA or \%CA were measured for $30 \mathrm{~min}$. Rearing behaviour (vertical activity) was also measured, as a distinct measure of novelty-induced exploratory behaviour (Lever et al. 2006), in an unfamiliar rectangular transparent box $(50 \times 25 \times 50 \mathrm{~cm})$ for $15 \mathrm{~min}$. The light in the testing rooms was set up at 100 lux.

Novelty seeking. Novelty preference was measured using a novelty-induced conditioned place preference procedure. The procedure was performed in boxes made of grey Plexiglas of two distinct compartments of equal size $(16 \times 16 \times \mathrm{cm})$ connected by a central zone $(16 \times 5 \mathrm{~cm})$, with distinct spatial configurations (one rectangular or triangular object at one of the angles) and two distinct floor textures (grooves or peaks), and that were totally closed at the time of the experiments to be isolated from visual cues in the testing room. Mice were exposed 25 min to one compartment ('familiar'). At the end of this habituation phase, the door isolating the familiar compartment from the other zones was opened to let the animal explore the whole box (central zone, familiar, and new compartment) for $15 \mathrm{~min}$. The index of novelty preference was calculated as the time spent in the new compartment/(time spent in the new compartment + time spent in the familiar compartment $) \times 100$. Light intensity into the boxes was about 0.20 lux. Before starting the 
experiments, we verified the absence of spontaneous preference for one of the compartments in a separate group of mice (data not shown).

Anxiety. Anxiety was evaluated in the EPM and LDB tests. \% of time spent in the EPM open arms and in their extremities (as complementary anxiety detection factor (Cruz et al. 1994)) and total distance moved were measured for $10 \mathrm{~min}$. The light in the testing room was set up at 20 lux. For LDB test, \% of time spent in the light side was measured for $5 \mathrm{~min}$. The EPM was elevated $50 \mathrm{~cm}$ from the floor, and consisted of two 'open arms', i.e., with no wall $(30 \times 7 \mathrm{~cm})$, and two 'closed arms', i.e. with 'high walls ( $30 \times 9 \times 7 \times 18 \mathrm{~cm})$, extending from a central platform $(7 \times 7 \mathrm{~cm})$. The entire structure was made of grey Plexiglas. The LDB measurements were $44 \times 21 \times 21 \mathrm{~cm}$. Mice were placed into a box with two chambers, one dark with black floor and walls, and one brightly lit (500 lux) with white floor and walls, connected by an opening.

\section{Drugs}

(-)-nicotine bitartrate (Sigma-Aldrich, St. Louis, Missouri) was dissolved in 0.9\% saline, and the $\mathrm{pH}$ adjusted to $7.2 \pm 0.1$ with $\mathrm{NaOH}(0.1 \mathrm{~N})$. Doses refer to free base. The different doses of nicotine were tested in independent groups of mice and injected intraperitoneally.

\section{Lentiviral expression vectors}

Mice were injected bilaterally into the VTA or dorsal hippocampus with LVs expressing enhanced green fluorescent protein (eGFP) ( $\mathrm{WT}^{\mathrm{GFP}}$ and $\alpha 5^{-/-\mathrm{GFP}}$ mice), bicistronic $\alpha 5 \mathrm{WT}$-IRES2-eGFP- $\left(\alpha 5^{-/-}\right.$ ${ }^{\alpha 5 \mathrm{WT}}$ mice) or $\alpha 5 \mathrm{D} 397 \mathrm{~N}-\mathrm{IRES} 2-\mathrm{eGFP}-\left(\alpha 5^{-/-\alpha 5 \mathrm{SNP}}\right.$ mice) cDNAs as described in detail in (Morel et al. 2014). Lentiviruses were derived from pHR' expression vectors (Naldini et al. 1996) with subsequent modifications (Maskos et al. 2005). The IRES element (Internal Ribosome Entry Site) enables the coordinated expression of two genes within the same vector, allowing the monitoring of the delivery of the gene of interest using eGFP visualization, as we previously validated for the B2-IRES2-eGFP construct (Avale et al. 2008; Maskos et al. 2005) that we have modified to create the $\alpha 5$ WT-IRES2-eGFP and $\alpha 5$ D397N-IRES2-eGFP vectors (Morel et al. 2014). Bicistronic expression of mouse WT or SNP $\alpha 5$ cDNAs and the eGFP cDNA were under the control of the mouse phosphoglycerate kinase (PGK) promoter. Viral particles were generated by co-transfection of HEK-293T cells by the vector plasmid, a packaging plasmid and an envelope plasmid using Lipofectamine Plus (Invitrogen, Carlsbad, CA, USA) according to the manufacturer's instructions. At 2 days after transfection, viral particles were harvested in the supernatant, treated with DNaseI and $\mathrm{MgCl}_{2}$, filtered through $0.45 \mathrm{~mm}$ pores, concentrated by ultracentrifugation and re-suspended in a small volume of phosphate-buffered saline (PBS). Viral stocks were stored in small aliquots at $-80^{\circ} \mathrm{C}$ before use. Viral titers were estimated by quantification of the p24 capsid protein using HIV-1 p24 antigen immunoassay (ZeptoMetrix Corporation, Buffalo, NY, USA) according to the manufacturer's instructions. 


\section{Stereotaxic procedure}

Mice were anesthetized using ketamine/xylazine in PBS. Each mouse was introduced into a stereotaxic frame adapted for use with mice. Lentivectors were injected bilaterally at: VTA: antero-posterior $3.4 \mathrm{~mm}$, lateral $\pm 0.5 \mathrm{~mm}$ from Bregma and $4.4 \mathrm{~mm}$ from the surface; dorsal hippocampus: antero-posterior -2.0 , lateral $\pm 1.5 \mathrm{~mm}$ from Bregma and $1.5 \mathrm{~mm}$ from the surface. All procedures were carried out in accordance with European Commission directives 219/1990 and 220/1990, and approved by Animalerie centrale and Medecine du travail, Institut Pasteur. The authors carrying out surgery hold an Animal Surgery Authorization from the French Ministry of Agriculture.

\section{Immunostaining}

To analyze eGFP transduction in brain cells, sections from GFP, $\alpha 5 \mathrm{WT}$ and $\alpha 5 \mathrm{SNP}$ vectorized mice were stained for GFP (Life Technologies SAS, France) and GFAP antibody (Sigma-Aldrich, St. Louis, Missouri) for astrocyte visualization. Fluorescence immunohistochemistry was performed as follows: free-floating VTA and hippocampus brain sections were incubated $1 \mathrm{~h}$ at $4{ }^{\circ} \mathrm{C}$ in a fixative solution of PBS containing $10 \%$ normal goat serum (Sigma, Lyon, France) and $0.2 \%$ Triton $\mathrm{X}-100$, and then overnight at $4{ }^{\circ} \mathrm{C}$ in PBS containing a rabbit anti-GFP at 1:2000 dilution or mouse anti-GFAP at 1:200 dilution, 2\% normal goat serum and 0.2\% Triton X-100. The next day, sections were rinsed with PBS and then incubated $3 \mathrm{~h}$ at room temperature with secondary antibody (AlexaFluor 488-conjugated anti-rabbit, Dylight 594-conjugated anti-mouse, Jackson Immunoresearch, London, UK) at 1:200 dilution in a solution of 2\% normal goat serum in PBS. After three rinses in PBS, slices were wet-mounted using Mowiol 4-88 (Calbiochem Corporation, La Jolla, CA, USA). NeuN (Millipore) staining was also tested but not clear-cut enough for reliable utilization in VTA and hippocampus (data not shown).

\section{In vivo electrophysiology}

Extracellular recordings of 5-HT neurons in the Dorsal Raphe Nucleus (DRN) of anesthetized mice were performed in vivo under basal conditions and after i.p. administration of nicotine (0.5 $\mathrm{mg} / \mathrm{kg})$. Mice were anaesthetized with chloral hydrate $(400 \mathrm{mg} / \mathrm{kg}$ i.p.) and placed into a stereotaxic frame. Additional anesthesia (50-100 mg/kg; i.p.) was given as necessary to maintain a full anesthetic state, characterized by the absence of response to a nociceptive tail pinch. Body temperature was maintained at $37^{\circ} \mathrm{C}$ throughout the experiments using a thermistor-controlled heating pad (Astro-Med, Elancourt, France). The recordings were performed as described in (Guiard et al. 2008) using single glass micropipettes (R\&D Scientific glass, Spencerville, MD, USA) that were preloaded with $2 \mathrm{M} \mathrm{NaCl}$ solution. These pipettes were pulled on a pipette puller (Narishige, Japan) with impedances ranging from 2.5 to $5 \mathrm{mV}$. They were positioned $0.2-0.5 \mathrm{~mm}$ posterior to the interaural line on the midline and lowered using a hydraulic micropositioner (Kopf 
Instruments) into the DRN, usually attained at a depth of 2.5-3.5 mm from the brain surface. To increase the signal-to-noise ratio, we used a current amplifier (BAK Electronics, Mount Airy, MD, USA) connected to the active filter Humbug (Quest scientific, DIPSI, Châtillon, France). The presumed DRN 5-HT neurons were then identified according to the criteria of Aghajanian and Vandermaelen (1982), (Aghajanian and Vandermaelen 1982) that is, a slow (0.5-2.5 Hz) and regular firing rate and long-duration, positive action potential (2-5 ms) bi- or triphasic extracellular waveform. Neuronal activity was recorded in real time using Spike2 software (Cambridge Electronic Design, Cambridge, UK), which was also used to analyze neurons offline. In each mouse, all presumed 5-HT neurons were recorded for 2 min to determine the means \pm SEM of 1) firing rate and 2) number of DRN 5-HT neurons per track in WT and $\alpha 5^{-/-}$mice. The last neuron was tested to determine the change in firing rate in response to the intraperitoneal administration of nicotine on DRN 5-HT neuronal activity for 1 min after approximately 10 min of stabilization.

\section{Microdialysis}

5-HT microdialysis. Concentric dialysis probes were made of cuprophan fibers (active length of $1.0 \mathrm{~mm}$, outer diameter $0.30 \mathrm{~mm}$ ). Mice were anaesthetized with chloral hydrate $(40 \mathrm{mg} / \mathrm{kg}$, i.p.), placed on a stereotaxic frame and implanted with a probe bilaterally into the dorsal hippocampus (Coordinates from Bregma (in $\mathrm{mm}$ ): anterior $=+1.6$, lateral $= \pm 1.3$, ventral $=-1.6$ ). Mice were allowed to recover from surgery overnight. On the next day, $20 \mathrm{hr}$ after the surgery, the probe was continuously perfused with an artificial CSF (composition in mmol/L: $\mathrm{NaCl} 147, \mathrm{KCl} 3.5, \mathrm{CaCl} 2$ 1.26, $\mathrm{MgCl} 21.2, \mathrm{NaH} 2 \mathrm{PO} 41.0, \mathrm{pH} 7.4 \pm 0.2$ ) and citalopram $1 \mu \mathrm{m}$ (Sigma) to increase and make detectable the basal extracellular levels of 5-HT as described in (Guilloux et al. 2006), at a flow rate of $1.5 \mu \mathrm{L} / \mathrm{min}$ using CMA/100 pump (Carnegie Medicine, Stockholm, Sweden). Dialysates were collected at 15 min intervals. Measurements of serotonin content were made using a High Performance Liquid Chromatography (HPLC) system (Ultremex 3u C18, 75 X 4.60 mm, particle size $3 \mu \mathrm{m}$, Phenomenex, Torrance, CA) coupled to an amperometric detector (VT03; Antec Leyden, The Netherlands). After 2 hours of balancing perfusion, 4 samples were collected to determine basal values over $60 \mathrm{~min}$. Then, animals received an i.p. systemic administration of $0.9 \% \mathrm{NaCl}$ and 4 samples were collected before i.p. systemic administration of $0.5 \mathrm{mg} / \mathrm{kg}$ of nicotine. Responses to nicotine administration were determined over a 120 - min period (8 samples). At the end of the day, mice were killed by an overdose of chloral hydrate. Brains were removed and stored at $+4^{\circ} \mathrm{C}$ in $2 \%$ formalin for 1 week. Brains were then cut using a Kryomat apparatus that maintained them at $-25^{\circ} \mathrm{C}$ to provide $40-\mu \mathrm{m}$ sections. Each section was photographed using a digital camera, and the implantation site was identified according to the 
mouse brain atlas. Only mice with probe confined in the dorsal hippocampus were used for subsequent data analysis

DA microdialysis. Mice were anesthetized with isofluorane and placed in a flat skull position in a Kopf stereotaxic apparatus fitted with a mouse adaptor. A guide cannula (CMA 7, CMA Microdialysis, Stockholm, Sweden) was inserted into the right nucleus accumbens (NAcb) (Coordinates from Bregma (in $\mathrm{mm})$ : anterior $=+1.5$, lateral $=-0.5$, ventral $=-5.2)$. The guide cannulae were permanently secured with epoxy glue. After surgery, the mice were placed in a Plexiglas cage and allowed to recover overnight. Twenty-four hours after surgery, the awake animal was gently restrained by the experimenter and a microdialysis probe (CMA 7/2, $2 \mathrm{~mm}$ dialysis membrane, CMA Microdialysis, Stockholm, Sweden) was inserted into the guide cannula. The probe was connected to a microinjection pump (CMA/100, CMA Microdialysis, Stockholm, Sweden) and perfused with artificial cerebrospinal fluid (aCSF: KCl $2.5 \mathrm{mM}, \mathrm{NaCl} 125 \mathrm{mM}$, $\mathrm{CaCl}_{2} 1.26 \mathrm{mM}, \mathrm{MgCl}_{2} 1.18 \mathrm{mM}, \mathrm{Na}_{2} \mathrm{HPO}_{4} 2 \mathrm{mM}, \mathrm{pH}$ 7.4) at a flow rate of $1.1 \mu \mathrm{l} / \mathrm{min}$. Starting 1 $\mathrm{h}$ after implantation, dialysate samples were collected every $20 \mathrm{~min}$ into glass vials containing $5 \mu \mathrm{l}$ of antioxidant solution (EDTA $0.27 \mathrm{mM}, 1$-cysteine $3.3 \mathrm{mM}$, ascorbic acid $0.5 \mathrm{mM}$, acetic acid 0.1M) $(27 \mu 1 / 20 \mathrm{~min}$ sample). Three hours after probe insertion animals received an injection of nicotine (0.1-1 mg/kg, i.p., free base) or saline. 6 samples were collected for basal values over 120 min. Responses to i.p. injection of nicotine $(0.1-1 \mathrm{mg} / \mathrm{kg})$ or saline were monitored for $120 \mathrm{~min}(6$ samples). For dopamine detection, a $20 \mu \mathrm{l}$ volume from each sample was injected into an Agilent 6410 triple quadrupole-mass spectrometer with an electrospray ion source operated in positive mode for detection of DA concentrations as previously described (Cannazza et al. 2012). Discovery HS-F5 column $(150 \mathrm{~mm} \times 2.1 \mathrm{~mm}, 3 \mu \mathrm{m})$ (Sigma-Aldrich, Milan, Italy) was used for chromatographic separations. The HPLC analyses were carried out using an elution profile composed of a first isocratic step water (formic acid 0.1\%): acetonitrile (ACN) 95:5 for 1.5 min and then to $30 \%$ of ACN over 6 min to separate DA from other analytes at $25^{\circ} \mathrm{C}$. The column was washed with $90 \%$ of $\mathrm{ACN}$ for $2.5 \mathrm{~min}$ followed by the equilibration of the column for 5 min with $5 \%$ ACN. The flow rate was $0.3 \mathrm{ml} / \mathrm{min}$. The chromatograms were integrated using Agilent Mass Hunter software. DA detection limit was $0.05 \mathrm{nM}$. At the end of each experiment, the animals were killed by rapid decapitation, brains were removed from the skull and the positions of the microdialysis probes were verified by visual inspection of the fresh tissue or the frozen brain during cut at the cryostat. The probe track was visible as a small hemorrhagic line. Data from brains with large hemorrhages (more than $1 \mathrm{~mm}$ in diameter) were discarded.

The implantation site was identified according to the mouse brain atlas (Paxinos and Franklin 2004).

\section{Statistical analysis}


Data were analyzed with Statistica (StatSoft, Inc., France).

Differences in behavioural and electrophysiological phenotypes between WT and $\alpha 5^{-/-}$mice were analyzed with unpaired Student's t-tests. Two-way ANOVAs were used to analyze the data for novelty preference (genotype as between- and environment as within-subject factors). Microdialysis data were analyzed with one or two-way repeated measures ANOVAs, (genotype and nicotine dose as between- and time as within-subject factors); paired and unpaired Student's ttests were used for genotype or drug treatment comparisons.

For comparison between GFP, $\alpha 5 \mathrm{WT}$ and $\alpha 5 \mathrm{SNP}$ vectorized groups, data were analyzed using one-way ANOVAs (group as between-subject factor).

Significant main effects $(\mathrm{p}<0.05)$ were further analyzed using LSD Fisher post-hoc tests.

\section{Results}

(Post-hoc multiple comparisons are reported in Figure legends).

\section{Responses to novelty and anxiety-related behaviours in $25^{-/-}$mice}

We first assessed whether the lack of the $\alpha 5$ subunit would influence the manifestation of behavioural phenotypes strongly associated with drug-, notably nicotine- addiction in humans (Batra et al. 2008; Kreek et al. 2005; Kushner et al. 2012; Salin-Pascual et al. 2003), and identified as predisposing factors for drug abuse in clinical (Batra et al. 2008; Kushner et al. 2012; Martin et al. 2004; Martin et al. 2002; Salin-Pascual et al. 2003; Sargent et al. 2010) and preclinical studies (Abreu-Villaca et al. 2006; Falco and Bevins 2015; Falco et al. 2014; Redolat et al. 2009; Suto et al. 2001; Wang et al. 2014). We addressed, in WT and $\alpha 5^{-/-}$mice $(n=10-12 /$ group), sensation seeking modeled as high novelty-induced exploratory behaviour / locomotor reactivity in novel inescapable environments (Belin et al. 2015; Belin and Deroche-Gamonet 2012), shown to predispose to higher nicotine self-administration (Redolat et al. 2009; Suto et al. 2001); novelty seeking modeled as high novelty preference in a free-choice procedure, that is proposed to reflect propensity for risky activity and predicts drug-, including nicotine- abuse (Abreu-Villaca et al. 2006; Batra et al. 2008; Belin and Deroche-Gamonet 2012; Redolat et al. 2009); and high anxiety that predicts transition to tobacco addiction and responsiveness to nicotine reward (Falco et al. 2014; Kushner et al. 2012; Wang et al. 2014; Wong et al. 2013).

We found that $\alpha 5^{-/-}$mice did not show increased locomotor reactivity to novelty compared to WT mice, with no differences observed between groups in the total distance travelled in a new inescapable open-field, or in other open-field parameters (Figure 1a). $\alpha 5^{-/-}$mice did not show increased novelty preference in a free choice situation, both WT and $\alpha 5^{-/-}$mice spending more time within the novel environment than the familiar one $[\mathrm{F}(1,22)=13.21, \mathrm{p}=0.001]$, with no differences 
in their \% of novelty preference (Figure 1b). $\alpha 5^{-/-}$mice displayed less rearing behaviour in a novel environment compared to WT mice $(\mathrm{p}=0.002)$ (Figure 1c). Moreover, $\alpha 5^{-/-}$mice showed high levels of anxiety in the EPM, with less time spent in the open arms $(p=0.016)$ and their extremities $(\mathrm{p}=0.024)$ compared to WT mice, with no differences in total distance travelled (Figure 1d). High anxiety-like phenotype was also observed in the LDB, with less time spent in the light compartment for $\alpha 5^{-/-}$mice compared to WT ( $\left.\mathrm{p}=0.0001\right)$ (Figure 1e). Thus, $\alpha 5^{-/-}$mice did not show enhanced responses to novelty. However, they displayed deficits in rearing behaviour and high anxiety-like behaviour.

\section{Effects of nicotine on $25^{-/-}$mice behavioural phenotypes}

Several factors have been proposed to explain nicotine abuse, with emphasis on a self-medication hypothesis for cognitive and mood disorders (Evans and Drobes 2009; Gehricke et al. 2007; Picciotto and Mineur 2014). We and others previously demonstrated that $\alpha 5^{-/-}$mice exhibit decreased sensitivity to nicotine, including decreased nicotine-elicited DAergic activation, reward, aversion and reward inhibition at high doses (Fowler et al. 2011; Morel et al. 2014). We next tested whether $\alpha 5^{-/-}$behavioural impairments may be alleviated by exposure to high doses of nicotine. We found that nicotine injections caused opposite effects in WT and $\alpha 5^{-/-}$mice $(n=8$ 16/group) on rearing [drug: $F(4,75)=7.617, p<0.0001$, drug $x$ group: $F(4,75)=8.730, p<0.001$ ] (Figure 2). This was also the case on anxiety levels, in the EPM [\% time spent in open arms : group: $\mathrm{F}(1,90)=25,97, \quad \mathrm{p}=0.0009 ; \quad$ drug: $\mathrm{F}(4,90)=7.064, \quad \mathrm{p}=0.002$, $\operatorname{drug} \mathrm{x}$ group: $\mathrm{F}(4,90)=9.635, \mathrm{p}=0.0002]$ [[\% time spent in extremities: group: $\mathrm{F}(1,90)=28,26, \mathrm{p}=0.0005$; drug: $\mathrm{F}(4,90)=4.809, \mathrm{p}=0.023$, drug $x$ group: $\mathrm{F}(4,90)=7.742, \mathrm{p}=0.001]$ and in the LDB [\% time spent in light side: group: $F(1,96)=4,72, p=0.032$; drug $x$ group: $F(4,96)=6.186, p=0.0002]$. Nicotine significantly decreased rearing in WT mice at the doses of $0.5 \mathrm{mg} / \mathrm{kg}(\mathrm{p}=0.0007)$ and $1 \mathrm{mg} / \mathrm{kg}$ ( $p<0.0001$ ), while restoring WT-like rearing levels in $\alpha 5^{-/-}$at the dose of $0.1 \mathrm{mg} / \mathrm{kg}(\mathrm{p}=0.036)$. The numbers of rearing was significantly different between WT and $\alpha 5^{-/-}$mice after saline $(p=0.014)$ and nicotine injection at the doses of $0.01(\mathrm{p}=0.008), 0.5(\mathrm{p}=0.010)$ and $1(\mathrm{p}=0004) \mathrm{mg} / \mathrm{kg}$ but similar at the dose of $0.1 \mathrm{mg} / \mathrm{kg}$ (Figure 2a). In the EPM, nicotine significantly decreased the \% of time spent in the open arms in WT mice, at the doses of $0.5 \mathrm{mg} / \mathrm{kg}(\mathrm{p}<0.0001)$ and $1 \mathrm{mg} / \mathrm{kg}$ $(\mathrm{p}<0.0001)$, an effect also seen for open arm extremities, at the doses of $0.5 \mathrm{mg} / \mathrm{kg}(\mathrm{p}<0.0001)$ and $1 \mathrm{mg} / \mathrm{kg}(\mathrm{p}<0.0001)$. The \% of time spent in the open arms and in their extremities was significantly different between WT and $\alpha 5^{-/-}$mice after saline $(\mathrm{p}<0.0001)$ and nicotine injection at the doses of 0.01 ( $\mathrm{p}=0.002$ and $\mathrm{p}=0.003$, respectively) and 0.1 ( $\mathrm{p}=0.008$ and $\mathrm{p}=0.0004$, respectively) $\mathrm{mg} / \mathrm{kg}$ but similar at the doses of 0.5 and $1 \mathrm{mg} / \mathrm{kg}$ (Figure 2b). In contrast, nicotine did not significantly affect anxiety in the EPM in $\alpha 5^{-/-}$mice (Figure 2b). In the LDB, nicotine 
decreased the $\%$ of time spent in the light side for WT mice, at the doses of $0.5 \mathrm{mg} / \mathrm{kg}(\mathrm{p}=0.014)$ and $1 \mathrm{mg} / \mathrm{kg}$ ( $\mathrm{p}=0.001$ ), while it significantly increased this parameter in $\alpha 5^{-/-}$mice at the dose of $0.5 \mathrm{mg} / \mathrm{kg}$ ( $\mathrm{p}=0.03$ ). The $\%$ of time spent in the light side was significantly different between WT and $\alpha 5^{-/-}$mice after saline $(\mathrm{p}=0.001)$ and nicotine injection at the dose of $0.01 \mathrm{mg} / \mathrm{kg}(\mathrm{p}=0.0002)$ but similar at the doses of $0.1,0.5$ and $1 \mathrm{mg} / \mathrm{kg}$ (Figure 2c). The doses of nicotine effective in rescuing rearing and LDB anxiety in $\alpha 5^{-/-}$mice did not affect motor features such as total distance moved in the EPM (Figure 3a) or open-field locomotor activity (Figure 3b).

\section{$N A c b D A$ release in response to nicotine in $\alpha 5^{-/-}$mice}

nAChRs are key regulators of mesolimbic DA neurons (Faure et al. 2014). We previously showed that anesthetized $\alpha 5^{-/-}$mice display decreased sensitivity to nicotine-induced VTA DA neuron response (Morel et al. 2014). To complete these data, we measured nicotine-elicited changes in DA perfusate levels in the NAcb, the main target of DA input from the VTA, from freely moving $\alpha 5^{-/-}$and WT mice (n=4-6/group) (Figure 4a, left). No differences were found in mean baseline DA concentrations between WT (mean \pm SEM: $0.57 \pm 0.09 \mathrm{nM})$ and $\alpha 5^{-/}$mice $(0.73 \pm 0.16 \mathrm{nM})$. Two-way repeated measures ANOVAs on DA outflow over time showed significant genotype effect $[F(1,22)=6.791, p=0.002]$ and nicotine dose effect $[F(3,22)=5.434, p=0.006]$ (Figure 4a, middle). Furthermore, DA perfusate levels during the first hour post-injection were significantly higher in response to nicotine at the doses of $0.2 \mathrm{mg} / \mathrm{kg}(\mathrm{p}=0.025), 0.4 \mathrm{mg} / \mathrm{kg}(\mathrm{p}=0.04)$ and 1 $\mathrm{mg} / \mathrm{kg}(\mathrm{p}=0.011)$ compared to saline in WT mice (Figure 4a, right). In $\alpha 5^{-/-}$mice, DA perfusate levels during the first hour post-injection were significantly higher in response to nicotine compared to saline only at the dose of $1 \mathrm{mg} / \mathrm{kg}(\mathrm{p}=0.021)$.

\section{DRN 5-HT neuron activity in response to nicotine in $\alpha 5^{-/-}$mice}

Besides DA, 5-HT plays an important role in drug abuse, including in nicotine dependence (Fletcher et al. 2008; Kirby et al. 2011; Muller and Homberg 2015). The involvement of 5-HT neurotransmission in nicotine action on the brain is firmly established, although the underlying mechanisms are much less elucidated (Hernandez-Lopez et al. 2013). Nicotine influences 5-HT activity, notably in the DRN that contains 5-HT neurons, and in the dorsal hippocampus, that contains 5-HT terminals (File et al. 2000; Hernandez-Lopez et al. 2013). Yet, the contribution of $\alpha 5^{*}$-nAChRs to 5-HT neurotransmission has not been assessed so far to our knowledge. We examined whether $\alpha 5^{-/-}$mice may show alterations in 5-HT neurotransmission, notably in response to nicotine, and performed extracellular recordings of DRN 5-HT neurons (Figure 4b). The mean firing frequency of 5-HT neurons was similar in WT and $\alpha 5^{-/-}$mice (n=5/group) (Figure 4b, left). However, the mean number of spontaneously active 5-HT neurons recorded per tract in $\alpha 5^{-/-}$mice 
was twice as high as in WT mice (p=0.001) ( $\mathrm{n}=11-17$ cells/group) (Figure 4b, middle). Strikingly, nicotine at the dose of $0.5 \mathrm{mg} / \mathrm{kg}$ caused differential effects on DRN 5-HT neuronal activity. In WT mice, nicotine inhibited 5-HT neuron firing rate, while in $\alpha 5^{-/-}$mice, nicotine increased 5-HT neuron firing rate (\% change from baseline, WT vs. $\alpha 5^{-/-}$mice: $\left.\mathrm{p}=0.0016\right)$ (Figure 5b, right).

\section{Hippocampus 5-HT extracellular levels in response to nicotine in $\alpha 5^{-/-}$mice}

We next measured nicotine-induced changes in extracellular 5-HT levels in the dorsal hippocampus, one of the discrete brain regions where 5-HT levels are affected in response to nicotine (Muller and Homberg 2015) and where $\alpha 5^{*}$-nAChRs are significantly expressed (Gensat, http://www.gensat.org/GeneProgressTracker.jsp?gensatGeneID=675) (Broide et al. 2002; Hsu et al. 2013; Salas et al. 2003; Sudweeks and Yakel 2000; Wada et al. 1990), in freely moving $\alpha 5^{-/-}$ and WT mice under citalopram perfusion (n=9-10/group) (Figure 4c). No differences were found

in mean baseline 5-HT concentrations between WT (mean \pm SEM: $0.26 \pm 0.02 \mathrm{nM}$ ) and $\alpha 5^{-/-}$mice $(0.29 \pm 0.03 \mathrm{nM})$. Repeated measures ANOVAs on 5-HT outflow over time showed significant time effect $[F(11,264)=6.380, p<0.0001]$ and time $x$ genotype interaction $[F(11,264)=4.780, p<0.0001]$. Post-hoc analysis showed that nicotine increased hippocampal 5-HT outflow during the first time sample post-injection in $\alpha 5^{-/-}$mice $(\mathrm{p}<0.0001)$ with no effect on WT mice (Figure 4c, middle). Analyzing the AUC values during the first hour post-injection further showed that 5-HT outflow was significantly higher after nicotine injection compared to saline in $\alpha 5^{-/-}$mice $(p=0.005)$ but not in WT mice (Figure 4c, right).

\section{Effects of a5WT or a5SNP re-expression in the VTA on $\alpha 5^{-/-}$mice behavioural phenotypes}

Since we have highlighted altered mesolimbic DA activity in response to nicotine in $\alpha 5^{-/-}$mice (Morel et al. 2014) (and present data, see above), and we also previously showed that nAChRs crucially contribute to VTA-dependent exploratory behaviour (Avale et al. 2008; Besson et al. 2007; Faure et al. 2014; Maskos et al. 2005), we next investigated the roles of VTA $\alpha 5 \mathrm{WT}$ and $\alpha 5 \mathrm{SNP}$ in $\alpha 5^{-\gamma_{-}}$behavioural phenotypes. For this, we used LV to transduce eGFP alone $\left(\mathrm{WT}^{\mathrm{GFP}}\right.$ and $\alpha 5^{-/-\mathrm{GFP}}$ mice), bi-cistronic $\alpha 5 \mathrm{WT}$ and eGFP (WT ${ }^{\alpha 5 \mathrm{WT}}$ and $\alpha 5^{-1-\alpha 5 \mathrm{WT}}$ mice), or bi-cistronic $\alpha 5 \mathrm{SNP}$ and eGFP ( $\mathrm{WT}^{\alpha 5 \mathrm{SNP}}$ and $\alpha 5^{-/ \alpha 5 \mathrm{SNP}}$ mice) selectively in the VTA as previously described in (Morel et al. 2014) (n=12-20/group) (Figure 5a). We detected eGFP expression in the whole VTA including in astrocytes (Figure 5a). VTA re-expression of $\alpha 5 \mathrm{WT}$, but not of $\alpha 5 \mathrm{SNP}$, restored WTlike rearing levels in $\alpha 5^{-/-}$mice [group: $\mathrm{F}(3,59)=7.88, \mathrm{p}=0.0002$ ] (Figure 5b). In contrast, anxiety levels were not affected by VTA $\alpha 5^{*}$-nAChRs re-expression in $\alpha 5^{-/-}$mice as measured by the $\%$ of time spent in the EPM open arms [group: $\mathrm{F}(3,62)=3.14, \mathrm{p}=0.032$ ] and their extremities [group: 
$\mathrm{F}(3,62)=3.40, \mathrm{p}=0.023$ ] (Figure 5c) and in the LDB light side [group: $\mathrm{F}(3,63)=8.95, \mathrm{p}<0.0001$ ] (Figure 5d).

\section{Effects of a5WT or a5SNP re-expression in the hippocampus on $25^{-/-}$mice behavioural phenotypes}

We have observed altered 5-HT activity in the dorsal hippocampus in $\alpha 5^{-/-}$mice (see above). The hippocampus, notably its dorsal part, has been particularly implicated in the action of nicotine on anxiety (Cheeta et al. 2000; Engin and Treit 2008; File et al. 2000; File et al. 1998; Piri et al. 2012; Seth et al. 2002). Also, this brain region expresses significant levels $\alpha 5^{*}$-nAChRs, presumably more than the other areas that have mainly been involved in the action of nicotine on anxiety such as the amygdala or the septum, according to the few studies reporting $\alpha 5^{*}$-nAChR brain distribution in mice (Gensat, http://www.gensat.org/index.html) (Broide et al. 2002; Hsu et al. 2013; Salas et al. 2003; Sudweeks and Yakel 2000; Wada et al. 1990). We next investigated the roles of hippocampal $\alpha 5 \mathrm{WT}$ and $\alpha 5 \mathrm{SNP}$ in the anxiety-like phenotype observed in $\alpha 5^{-/-}$mice. In mice transduced with bi-cistronic LV in the hippocampus, we detected eGFP mostly in the CA1 area, dentate gyrus, including in astrocytes $\left(n=11-20 /\right.$ group) (Figure 6a). Hippocampal $\alpha{ }^{*_{-}}$ nAChR re-expression, contrary to VTA re-expression, did not rescue rearing behaviour in $\alpha 5^{-/-}$ mice [group: $\mathrm{F}(3,46)=5.94, \mathrm{p}=0.002$ ] (Figures 6b). However, hippocampal $\alpha 5 \mathrm{WT}$ re-expression resulted in partial rescue of anxiety levels: $\alpha 5^{-/-\alpha 5 \mathrm{WT}}$ mice displayed anxiety at intermediate levels between $\mathrm{WT}^{\mathrm{GFP}}$ and $\alpha 5^{-/-\mathrm{GFP}}$, as measured by the $\%$ of time spent in the EPM open arms [group: $\mathrm{F}(3,59)=6.40, \mathrm{p}=0.0008$ ] and their extremities [group: $\mathrm{F}(3,59)=4.02, \mathrm{p}=0.0011$ ] (Figure 6c), as well as in the LDB light side [group: $\mathrm{F}(3,64)=3.85$, $\mathrm{p}=0.013$ ] (Figure 6d). By contrast, expressing the $\alpha 5$ SNP did not alleviate anxiety in the EPM (Figure 6c) or the LDB (Figure 6d).

\section{Discussion}

We demonstrated that $\alpha 5^{-/-}$mice display deficits in rearing behaviour and enhanced anxiety. These two phenotypes could be rescued by exposure to nicotine while nicotine caused $\alpha 5^{-/-}$-like impairments in WT mice. This was not related to nicotine-elicited general locomotor modifications. We also observed that higher doses of nicotine are required to increase DA release in the NAcb in $\alpha 5^{-/-}$mice. Furthermore, we identified for the first time altered 5-HT activity in $\alpha 5^{-/-}$ mice, with an increased number of spontaneously active 5-HT neurons in the DRN and nicotineelicited increase in 5-HT release in the dorsal hippocampus at a dose ineffective on this parameter in WT mice. Finally, re-expressing the $\alpha 5 \mathrm{WT}$ gene in the VTA and the hippocampus of $\alpha 5^{-/-}$mice restored WT levels of rearing behaviour and anxiety, respectively, while re-expressing the $\alpha 5 \mathrm{SNP}$ resulted in knockout-like phenotypes on both parameters. 


\section{Alterations in $\alpha 5^{*}$-nAChRs and addiction vulnerability behavioural phenotypes}

Only a proportion of individuals exposed to drugs develop addiction, as this pathology requires the interaction between polygenic and external factors (Belin et al. 2015; Degenhardt et al. 2008). The $\alpha 5$ gene constitutes a very interesting candidate for studying vulnerability to tobacco addiction, and potentially for novel treatment strategies, since the $\alpha 5$ SNP (Bierut et al. 2008; Frahm et al. 2011; Kuryatov et al. 2011) is frequent in Caucasians (Bierut et al. 2008) and consistently associated with heavy smoking (Bierut et al. 2008; Improgo et al. 2010; Saccone et al. 2007; Ware et al. 2012). We previously showed that deletion of the $\alpha 5$ gene and expression of the $\alpha 5 \mathrm{SNP}$ in the VTA of $\alpha 5^{-/-}$mice results in decreased sensitivity to nicotine reward in a self-administration procedure (Morel et al. 2014). It may appear counterintuitive that subjects with impaired $\alpha{ }^{*} *_{-}$ nAChR function would be less sensitive to nicotine reward and yet show higher risk for nicotine addiction. We postulated that there may be additional mechanisms underlying the impact of $\alpha{ }^{*_{-}}$ $\mathrm{nAChR}$ dysfunction on the risk for heavy smoking. Specific behavioural endophenotypes of presumed genetic origin (e.g. trait anxiety, high response to novelty and impulsivity) were shown to contribute to drug addiction according to different modalities (Belin et al. 2015).

High responses to novelty were shown to predispose to greater propensity to acquire drug, including nicotine, self-administration and to loss of control over drug use (Abreu-Villaca et al. 2006; Batra et al. 2008; Belin et al. 2015; Belin and Deroche-Gamonet 2012; Redolat et al. 2009; Suto et al. 2001). Also high impulsivity impacts both processes (Belin et al. 2015; Diergaarde et al. 2008). Here, we did not observe enhanced response to novelty in $\alpha 5^{-/-}$mice and a previous study showed no impulsive phenotype in these mice in a 5-choice serial reaction time task (Bailey et al. 2010), suggesting that $\alpha 5^{*}$-nAChRs do not impact these processes. But mood and cognitive disorders appear to confer vulnerability to nicotine abuse according to dissociable processes more related to "coping" or self-medication strategy, to regulate affective or cognitive symptoms (Gehricke et al. 2007). This is particularly well documented for high anxiety (Baker et al. 2004; Kushner et al. 2012; Picciotto et al. 2002; Salin-Pascual et al. 2003; Sonntag et al. 2000; Wong et al. 2013). Here we demonstrate that both $\alpha 5$ gene deletion and targeted $\alpha 5$ SNP expression lead to decreased rearing and increased anxiety-like behaviour. Rearing has been proposed to have a major exploratory information-gathering function (Lever et al. 2006). It can also reflect other factors such as fear and anxiety, suggesting that the decreased rearing and increased anxiety we observed in $\alpha 5^{-/-}$mice may be associated phenotypes, although our $\alpha 5^{*}$-nAChR targeted reexpression experiments showed that rescuing one of these phenotypes did not affect the other. Exploratory behaviour reflects many neuropsychological and genetic correlates. Fine exploratory 
activity such as rearing can be dissociated from general ambulatory activity, with nAChRs independently modulating these behaviours (Avale et al. 2008; Somm et al. 2014). $\alpha 5$ impairmentrelated deficits in rearing, which we found distinct from general locomotor dysfunction, indicate abnormal response to novel environment features that might be associated with attentional or motivational impairments. Interestingly, $\alpha 5^{-/-}$mice also display deficits in attention under highly demanding conditions (Bailey et al. 2010).

Studies supporting the self-medication hypothesis show that nicotine is particularly effective in reducing depression, anxiety and in improving attention in psychiatric sub-populations (Gehricke et al. 2007; Picciotto et al. 2002; Picciotto and Mineur 2014). Consistently, here, in $\alpha 5^{-/-}$mice, nicotine alleviates impairments in both rearing and anxiety, at doses that have opposite effects in control mice. Interestingly, anxiety sensitivity has been shown to predict greater positive affect in response to acute nicotine in smokers (Wong et al. 2013). While anxiogenic nicotine action in control mice was observed in the LDB and the EPM, nicotine rescued WT anxiety levels in $\alpha 5^{-/-}$ mice in the LDB with no significant effects in the EPM. Both tests are based on approachavoidance conflict, yet differences in the external input such as elevation vs. bright illumination may cause different subjective experiences with different sensitivity to pharmacological manipulation. As regards nicotine rescue of rearing behaviour in $\alpha 5^{-/-}$mice, cholinergic neurotransmission is a key regulator of exploratory behaviour through DAergic modulation (Faure et al. 2014). Accordingly, $\alpha 5^{*}$-nAChRs critically contribute to nicotine-elicited activation of the mesolimbic system, with higher doses of nicotine required to enhance NAcb DA release in $\alpha 5^{-/-}$ mice, similar to VTA neuron activity (Morel et al. 2014).

\section{Identification of the VTA and the hippocampus as key areas for $\alpha 5^{-/-}$mice behavioural phenotypes}

Our LV-based targeted $\alpha 5$ re-expression strategy identified that VTA, but not hippocampal, $\alpha{ }^{*} *_{-}$ nAChRs regulate rearing behaviour. Mice knockout for the $\beta 2$ subunit show high ambulation and low fine exploration (Besson et al. 2007; Granon et al. 2003), the latter being rescued by VTA $\beta 2$ re-expression (Avale et al. 2008). Interestingly, this unbalanced exploratory behaviour was associated with impairments in VTA DA activity, and rescued by nicotine exposure (Besson et al. 2007). In the VTA, $\alpha 5$ is associated with $\alpha 4$ and $\beta 2$ subunits (Millar and Gotti 2009). Our present results suggest that $\alpha 5$ may be a key partner of VTA $\alpha 4 \beta 2 *$-nAChR function in fine exploratory control. Further, $\alpha 5^{*}$-nAChRs expressed in the hippocampus, but not in the VTA, modulate anxiety. The hippocampus has been widely implicated in anxiety and nicotine effects on anxiety (Cheeta et al. 2000; Engin and Treit 2008; File et al. 2000; File et al. 1998; Piri et al. 2012), 
although the role of the different nAChRs is not well established (Picciotto et al. 2002). Here we observed partial rescue of the anxiety phenotype after hippocampal $\alpha 5 *$-nAChR re-expression. The contribution of $\alpha 5^{*}$-nAChRs in the lateral septum, DRN or amygdala (Picciotto et al. 2002; Seth et al. 2002), might be required for fully balanced anxiety processing. With our LV and ubiquitous PGK promoter, transduction is not cell-type specific. The endogenous $\alpha 5$ expression in the hippocampus is not well documented. Two publications suggest that in the hippocampal CA1 region of $\mathrm{C} 57 \mathrm{BL} / 6 \mathrm{~J}$ mice, $\mathrm{nAChR}$ expression is found on astrocytes and GABAergic interneurons (Gahring et al. 2004a; Gahring et al. 2004b). Hippocampal astrocytes were recently implicated in anxiolytic-like responses (Quesseveur et al. 2013). In the CA1 region, GABAergic interneurons are the main neuronal type expressing high affinity nicotinic receptors (Sudweeks and Yakel 2000). An important population of these interneurons is also receptive to serotonergic modulation from the DRN (Chittajallu et al. 2013). Further investigations beyond the scope of the present work are required to identify the role of $\alpha 5$ expression on different cell types.

\section{A key role for $\alpha 5^{*}$-nAChRs in 5-HT neurotransmission}

We reveal impairments in spontaneous and nicotine-elicited 5-HT activity in $\alpha 5^{-/-}$mice. DRN 5HT neurons are either silent or spontaneously active with slow regular firing pattern (Vandermaelen and Aghajanian 1983). The number of spontaneously active 5-HT neurons is enhanced in $\alpha 5^{-/-}$mice, indicating that the absence of $\alpha 5$ changes the excitability of 5-HT neurons. DRN cholinergic input derives from laterodorsal tegmental and pedunculopontine nuclei and was proposed to modulate DRN 5-HT activity, through nAChRs located on noradrenergic and glutamatergic neurons arising from many areas (Hernandez-Lopez et al. 2013; Li et al. 1998; Soiza-Reilly and Commons 2011). DRN glutamate neurotransmission influences 5-HT tone through $\alpha 4 \beta 2 *$-nAChRs (Garduno et al. 2012). Our data indicate that $\alpha 5$ contributes to synaptic gating of $\alpha 4 \beta 2 *$-nAChRs in preventing the transition from silent to active state of DRN 5-HT neurons. We also found that nicotine has differential effects on DRN 5-HT neuron firing and hippocampal 5-HT release between WT and $\alpha 5^{-/-}$mice. Alterations in the number of spontaneously active 5-HT neurons in $\alpha 5^{-/-}$mice might also contribute to the differential responses of these neurons in WT and $\alpha 5^{-/-}$mice (File et al. 2000; Seth et al. 2002). The highest levels of $\alpha 5$ expression in the brain are found by far in the interpeduncular nucleus (IPN) (Gensat, http://www.gensat.org/GeneProgressTracker.jsp?gensatGeneID=675) (Hsu et al. 2013), mostly on GABA neurons (Hsu et al. 2013). In WT animals, nicotine may thus decrease DRN 5-HT neuron firing by activating, through $\alpha 5^{*}$-nAChRs, IPN GABA inhibitory neurons projecting to the DRN (Montone et al. 1988; Pollak Dorocic et al. 2014). The lack of $\alpha 5^{*}$-nAChRs may prevent IPNelicited inhibition of 5-HT DRN neurons, favoring an excitation of these neurons and an increase 
in 5-HT release in hippocampal 5-HT terminals in response to nicotine, as we observed in $\alpha 5^{-/-}$ mice.

These results demonstrate that alterations in $\alpha 5^{*}$-nAChRs result in vulnerability phenotypes, decreased rearing behaviour and enhanced anxiety, which depend at least partly upon the VTA and the hippocampus, respectively. Exposure to high doses of nicotine rescued these phenotypes in $\alpha 5$

I- mice, suggesting that self-medication to reduce behavioural or affective disorders may be a critical factor for the initiation and maintenance of smoking in subjects with altered cholinergic signaling through $\alpha 5^{*}$-nAChR dysfunction.

\section{References}

Abreu-Villaca Y, Queiroz-Gomes Fdo E, Dal Monte AP, Filgueiras CC, Manhaes AC (2006) Individual differences in novelty-seeking behaviour but not in anxiety response to a new environment can predict nicotine consumption in adolescent C57BL/6 mice. Behavioural brain research 167: 175-82.

Aghajanian GK, Vandermaelen CP (1982) Intracellular identification of central noradrenergic and serotonergic neurons by a new double labeling procedure. The Journal of neuroscience : the official journal of the Society for Neuroscience 2: 1786-92.

Avale ME, Faure P, Pons S, Robledo P, Deltheil T, David DJ, Gardier AM, Maldonado R, Granon S, Changeux JP, Maskos U (2008) Interplay of beta2* nicotinic receptors and dopamine pathways in the control of spontaneous locomotion. Proceedings of the National Academy of Sciences of the United States of America 105: 15991-6.

Bailey CD, De Biasi M, Fletcher PJ, Lambe EK (2010) The nicotinic acetylcholine receptor alpha5 subunit plays a key role in attention circuitry and accuracy. The Journal of neuroscience : the official journal of the Society for Neuroscience 30: 9241-52.

Baker TB, Brandon TH, Chassin L (2004) Motivational influences on cigarette smoking. Annual review of psychology 55: 463-91.

Batra A, Collins SE, Torchalla I, Schroter M, Buchkremer G (2008) Multidimensional smoker profiles and their prediction of smoking following a pharmacobehavioural intervention. Journal of substance abuse treatment 35: 41-52.

Belin D, Belin-Rauscent A, Everitt BJ, Dalley JW (2015) In search of predictive endophenotypes in addiction: insights from preclinical research. Genes, brain, and behaviour.

Belin D, Deroche-Gamonet V (2012) Responses to novelty and vulnerability to cocaine addiction: contribution of a multi-symptomatic animal model. Cold Spring Harbor perspectives in medicine 2.

Berrettini WH, Doyle GA (2012) The CHRNA5-A3-B4 gene cluster in nicotine addiction. Molecular psychiatry 17: 856-66.

Besson M, Granon S, Mameli-Engvall M, Cloez-Tayarani I, Maubourguet N, Cormier A, Cazala P, David V, Changeux JP, Faure P (2007) Long-term effects of chronic nicotine exposure on brain nicotinic receptors. Proceedings of the National Academy of Sciences of the United States of America 104: 8155-60.

Bierut LJ, Stitzel JA, Wang JC, Hinrichs AL, Grucza RA, Xuei X, Saccone NL, Saccone SF, Bertelsen S, Fox L, Horton WJ, Breslau N, Budde J, Cloninger CR, Dick DM, Foroud T, Hatsukami D, Hesselbrock V, Johnson EO, Kramer J, Kuperman S, Madden PA, Mayo K, Nurnberger J, Jr., Pomerleau O, Porjesz B, Reyes O, Schuckit M, Swan G, Tischfield JA, 
Edenberg HJ, Rice JP, Goate AM (2008) Variants in nicotinic receptors and risk for nicotine dependence. The American journal of psychiatry 165: 1163-71.

Broide RS, Salas R, Ji D, Paylor R, Patrick JW, Dani JA, De Biasi M (2002) Increased sensitivity to nicotine-induced seizures in mice expressing the L250T alpha 7 nicotinic acetylcholine receptor mutation. Molecular pharmacology 61: 695-705.

Cannazza G, Carrozzo MM, Cazzato AS, Bretis IM, Troisi L, Parenti C, Braghiroli D, Guiducci S, Zoli M (2012) Simultaneous measurement of adenosine, dopamine, acetylcholine and 5hydroxytryptamine in cerebral mice microdialysis samples by LC-ESI-MS/MS. Journal of pharmaceutical and biomedical analysis 71: 183-6.

Changeux JP (2010) Nicotine addiction and nicotinic receptors: lessons from genetically modified mice. Nature reviews Neuroscience 11: 389-401.

Cheeta S, Kenny PJ, File SE (2000) Hippocampal and septal injections of nicotine and 8-OHDPAT distinguish among different animal tests of anxiety. Progress in neuropsychopharmacology \& biological psychiatry 24: 1053-67.

Chittajallu R, Craig MT, McFarland A, Yuan X, Gerfen S, Tricoire L, Erkkila B, Barron SC, Lopez CM, Liang BJ, Jeffries BW, Pelkey KA, McBain CJ (2013) Dual origins of functionally distinct O-LM interneurons revealed by differential 5-HT(3A)R expression. Nature neuroscience 16: 1598-607.

Cruz AP, Frei F, Graeff FG (1994) Ethopharmacological analysis of rat behaviour on the elevated plus-maze. Pharmacology, biochemistry, and behaviour 49: 171-6.

Degenhardt L, Chiu WT, Sampson N, Kessler RC, Anthony JC, Angermeyer M, Bruffaerts R, de Girolamo G, Gureje O, Huang Y, Karam A, Kostyuchenko S, Lepine JP, Mora ME, Neumark Y, Ormel JH, Pinto-Meza A, Posada-Villa J, Stein DJ, Takeshima T, Wells JE (2008) Toward a global view of alcohol, tobacco, cannabis, and cocaine use: findings from the WHO World Mental Health Surveys. PLoS medicine 5: e141.

Diergaarde L, Pattij T, Poortvliet I, Hogenboom F, de Vries W, Schoffelmeer AN, De Vries TJ (2008) Impulsive choice and impulsive action predict vulnerability to distinct stages of nicotine seeking in rats. Biological psychiatry 63: 301-8.

Engin E, Treit D (2008) The effects of intra-cerebral drug infusions on animals' unconditioned fear reactions: a systematic review. Progress in neuro-psychopharmacology \& biological psychiatry 32: 1399-419.

Evans DE, Drobes DJ (2009) Nicotine self-medication of cognitive-attentional processing. Addiction biology 14: 32-42.

Exley R, McIntosh JM, Marks MJ, Maskos U, Cragg SJ (2012) Striatal alpha5 nicotinic receptor subunit regulates dopamine transmission in dorsal striatum. The Journal of neuroscience : the official journal of the Society for Neuroscience 32: 2352-6.

Falco AM, Bevins RA (2015) Individual differences in the behavioural effects of nicotine: A review of the preclinical animal literature. Pharmacology, biochemistry, and behaviour 138: 80-90.

Falco AM, McDonald CG, Smith RF (2014) Anxiety status affects nicotine- and baclofen-induced locomotor activity, anxiety, and single-trial conditioned place preference in male adolescent rats. Developmental psychobiology 56: 1352-64.

Faure P, Tolu S, Valverde S, Naude J (2014) Role of nicotinic acetylcholine receptors in regulating dopamine neuron activity. Neuroscience 282C: 86-100.

File SE, Kenny PJ, Cheeta S (2000) The role of the dorsal hippocampal serotonergic and cholinergic systems in the modulation of anxiety. Pharmacology, biochemistry, and behaviour 66: 65-72.

File SE, Kenny PJ, Ouagazzal AM (1998) Bimodal modulation by nicotine of anxiety in the social interaction test: role of the dorsal hippocampus. Behavioural neuroscience 112: 1423-9.

Fletcher PJ, Le AD, Higgins GA (2008) Serotonin receptors as potential targets for modulation of nicotine use and dependence. Progress in brain research 172: 361-83. 
Fowler CD, Lu Q, Johnson PM, Marks MJ, Kenny PJ (2011) Habenular alpha5 nicotinic receptor subunit signalling controls nicotine intake. Nature 471: 597-601.

Frahm S, Slimak MA, Ferrarese L, Santos-Torres J, Antolin-Fontes B, Auer S, Filkin S, Pons S, Fontaine JF, Tsetlin V, Maskos U, Ibanez-Tallon I (2011) Aversion to nicotine is regulated by the balanced activity of beta4 and alpha5 nicotinic receptor subunits in the medial habenula. Neuron 70: 522-35.

Gahring LC, Persiyanov K, Dunn D, Weiss R, Meyer EL, Rogers SW (2004a) Mouse strainspecific nicotinic acetylcholine receptor expression by inhibitory interneurons and astrocytes in the dorsal hippocampus. The Journal of comparative neurology 468: 334-46.

Gahring LC, Persiyanov K, Rogers SW (2004b) Neuronal and astrocyte expression of nicotinic receptor subunit beta4 in the adult mouse brain. The Journal of comparative neurology 468: 322-33.

Garduno J, Galindo-Charles L, Jimenez-Rodriguez J, Galarraga E, Tapia D, Mihailescu S, Hernandez-Lopez S (2012) Presynaptic alpha4beta2 nicotinic acetylcholine receptors increase glutamate release and serotonin neuron excitability in the dorsal raphe nucleus. The Journal of neuroscience : the official journal of the Society for Neuroscience 32: 15148-57.

Gehricke JG, Loughlin SE, Whalen CK, Potkin SG, Fallon JH, Jamner LD, Belluzzi JD, Leslie FM (2007) Smoking to self-medicate attentional and emotional dysfunctions. Nicotine \& tobacco research : official journal of the Society for Research on Nicotine and Tobacco 9 Suppl 4: S523-36.

Granon S, Faure P, Changeux JP (2003) Executive and social behaviours under nicotinic receptor regulation. Proceedings of the National Academy of Sciences of the United States of America 100: 9596-601.

Greenbaum L, Lerer B (2009) Differential contribution of genetic variation in multiple brain nicotinic cholinergic receptors to nicotine dependence: recent progress and emerging open questions. Molecular psychiatry 14: 912-45.

Grucza RA, Wang JC, Stitzel JA, Hinrichs AL, Saccone SF, Saccone NL, Bucholz KK, Cloninger CR, Neuman RJ, Budde JP, Fox L, Bertelsen S, Kramer J, Hesselbrock V, Tischfield J, Nurnberger JI, Jr., Almasy L, Porjesz B, Kuperman S, Schuckit MA, Edenberg HJ, Rice JP, Goate AM, Bierut LJ (2008) A risk allele for nicotine dependence in CHRNA5 is a protective allele for cocaine dependence. Biological psychiatry 64: 922-9.

Guiard BP, El Mansari M, Merali Z, Blier P (2008) Functional interactions between dopamine, serotonin and norepinephrine neurons: an in-vivo electrophysiological study in rats with monoaminergic lesions. The international journal of neuropsychopharmacology / official scientific journal of the Collegium Internationale Neuropsychopharmacologicum 11: 62539.

Guilloux JP, David DJ, Guiard BP, Chenu F, Reperant C, Toth M, Bourin M, Gardier AM (2006) Blockade of 5-HT1A receptors by (+/-)-pindolol potentiates cortical 5-HT outflow, but not antidepressant-like activity of paroxetine: microdialysis and behavioural approaches in 5HT1A receptor knockout mice. Neuropsychopharmacology : official publication of the American College of Neuropsychopharmacology 31: 2162-72.

Hernandez-Lopez S, Garduno J, Mihailescu S (2013) Nicotinic modulation of serotonergic activity in the dorsal raphe nucleus. Reviews in the neurosciences 24: 455-69.

Hsu YW, Tempest L, Quina LA, Wei AD, Zeng H, Turner EE (2013) Medial habenula output circuit mediated by alpha5 nicotinic receptor-expressing GABAergic neurons in the interpeduncular nucleus. The Journal of neuroscience : the official journal of the Society for Neuroscience 33: 18022-35.

Improgo MR, Scofield MD, Tapper AR, Gardner PD (2010) The nicotinic acetylcholine receptor CHRNA5/A3/B4 gene cluster: dual role in nicotine addiction and lung cancer. Progress in neurobiology 92: 212-26. 
Jackson KJ, Marks MJ, Vann RE, Chen X, Gamage TF, Warner JA, Damaj MI (2010) Role of alpha5 nicotinic acetylcholine receptors in pharmacological and behavioural effects of nicotine in mice. The Journal of pharmacology and experimental therapeutics 334: 137-46.

Kirby LG, Zeeb FD, Winstanley CA (2011) Contributions of serotonin in addiction vulnerability. Neuropharmacology 61: 421-32.

Kreek MJ, Nielsen DA, Butelman ER, LaForge KS (2005) Genetic influences on impulsivity, risk taking, stress responsivity and vulnerability to drug abuse and addiction. Nature neuroscience 8: 1450-7.

Kuryatov A, Berrettini W, Lindstrom J (2011) Acetylcholine receptor (AChR) alpha5 subunit variant associated with risk for nicotine dependence and lung cancer reduces (alpha4beta2)(2)alpha5 AChR function. Molecular pharmacology 79: 119-25.

Kuryatov A, Onksen J, Lindstrom J (2008) Roles of accessory subunits in alpha4beta2(*) nicotinic receptors. Molecular pharmacology 74: 132-43.

Kushner MG, Menary KR, Maurer EW, Thuras P (2012) Greater elevation in risk for nicotine dependence per pack of cigarettes smoked among those with an anxiety disorder. Journal of studies on alcohol and drugs 73: 920-4.

Lever C, Burton S, O'Keefe J (2006) Rearing on hind legs, environmental novelty, and the hippocampal formation. Reviews in the neurosciences 17: 111-33.

Li X, Rainnie DG, McCarley RW, Greene RW (1998) Presynaptic nicotinic receptors facilitate monoaminergic transmission. The Journal of neuroscience : the official journal of the Society for Neuroscience 18: 1904-12.

Martin CA, Kelly TH, Rayens MK, Brogli B, Himelreich K, Brenzel A, Bingcang CM, Omar H (2004) Sensation seeking and symptoms of disruptive disorder: association with nicotine, alcohol, and marijuana use in early and mid-adolescence. Psychological reports 94: 107582.

Martin CA, Kelly TH, Rayens MK, Brogli BR, Brenzel A, Smith WJ, Omar HA (2002) Sensation seeking, puberty, and nicotine, alcohol, and marijuana use in adolescence. Journal of the American Academy of Child and Adolescent Psychiatry 41: 1495-502.

Maskos U, Molles BE, Pons S, Besson M, Guiard BP, Guilloux JP, Evrard A, Cazala P, Cormier A, Mameli-Engvall M, Dufour N, Cloez-Tayarani I, Bemelmans AP, Mallet J, Gardier AM, David V, Faure P, Granon S, Changeux JP (2005) Nicotine reinforcement and cognition restored by targeted expression of nicotinic receptors. Nature 436: 103-7.

Millar NS, Gotti C (2009) Diversity of vertebrate nicotinic acetylcholine receptors. Neuropharmacology 56: 237-46.

Montone KT, Fass B, Hamill GS (1988) Serotonergic and nonserotonergic projections from the rat interpeduncular nucleus to the septum, hippocampal formation and raphe: a combined immunocytochemical and fluorescent retrograde labelling study of neurons in the apical subnucleus. Brain research bulletin 20: 233-40.

Morel C, Fattore L, Pons S, Hay YA, Marti F, Lambolez B, De Biasi M, Lathrop M, Fratta W, Maskos U, Faure $\mathrm{P}$ (2014) Nicotine consumption is regulated by a human polymorphism in dopamine neurons. Molecular psychiatry 19: 930-6.

Muller CP, Homberg JR (2015) The role of serotonin in drug use and addiction. Behavioural brain research 277: 146-92.

Naldini L, Blomer U, Gallay P, Ory D, Mulligan R, Gage FH, Verma IM, Trono D (1996) In vivo gene delivery and stable transduction of nondividing cells by a lentiviral vector. Science 272: $263-7$.

Paxinos G, Franklin KBJ (2004) The Mouse Brain in Stereotaxic Coordinates. Gulf Professional Publishing

Picciotto MR, Brunzell DH, Caldarone BJ (2002) Effect of nicotine and nicotinic receptors on anxiety and depression. Neuroreport 13: 1097-106.

Picciotto MR, Kenny PJ (2013) Molecular mechanisms underlying behaviours related to nicotine addiction. Cold Spring Harbor perspectives in medicine 3: a012112. 
Picciotto MR, Mineur YS (2014) Molecules and circuits involved in nicotine addiction: The many faces of smoking. Neuropharmacology 76 Pt B: 545-53.

Piri M, Nasehi M, Shahab Z, Zarrindast MR (2012) The effects of nicotine on nitric oxide induced anxiogenic-like behaviours in the dorsal hippocampus. Neuroscience letters 528: 93-8.

Pollak Dorocic I, Furth D, Xuan Y, Johansson Y, Pozzi L, Silberberg G, Carlen M, Meletis K (2014) A whole-brain atlas of inputs to serotonergic neurons of the dorsal and median raphe nuclei. Neuron 83: 663-78.

Quesseveur G, David DJ, Gaillard MC, Pla P, Wu MV, Nguyen HT, Nicolas V, Auregan G, David I, Dranovsky A, Hantraye P, Hen R, Gardier AM, Deglon N, Guiard BP (2013) BDNF overexpression in mouse hippocampal astrocytes promotes local neurogenesis and elicits anxiolytic-like activities. Translational psychiatry 3: e253.

Ramirez-Latorre J, Yu CR, Qu X, Perin F, Karlin A, Role L (1996) Functional contributions of alpha5 subunit to neuronal acetylcholine receptor channels. Nature 380: 347-51.

Redolat R, Perez-Martinez A, Carrasco MC, Mesa P (2009) Individual differences in noveltyseeking and behavioural responses to nicotine: a review of animal studies. Current drug abuse reviews 2: 230-42.

Saccone SF, Hinrichs AL, Saccone NL, Chase GA, Konvicka K, Madden PA, Breslau N, Johnson EO, Hatsukami D, Pomerleau O, Swan GE, Goate AM, Rutter J, Bertelsen S, Fox L, Fugman D, Martin NG, Montgomery GW, Wang JC, Ballinger DG, Rice JP, Bierut LJ (2007) Cholinergic nicotinic receptor genes implicated in a nicotine dependence association study targeting 348 candidate genes with 3713 SNPs. Human molecular genetics 16: 36-49.

Salas R, Orr-Urtreger A, Broide RS, Beaudet A, Paylor R, De Biasi M (2003) The nicotinic acetylcholine receptor subunit alpha 5 mediates short-term effects of nicotine in vivo. Molecular pharmacology 63: 1059-66.

Salas R, Sturm R, Boulter J, De Biasi M (2009) Nicotinic receptors in the habenulointerpeduncular system are necessary for nicotine withdrawal in mice. The Journal of neuroscience : the official journal of the Society for Neuroscience 29: 3014-8.

Salin-Pascual RJ, Alcocer-Castillejos NV, Alejo-Galarza G (2003) Nicotine dependence and psychiatric disorders. Revista de investigacion clinica; organo del Hospital de Enfermedades de la Nutricion 55: 677-93.

Sargent JD, Tanski S, Stoolmiller M, Hanewinkel R (2010) Using sensation seeking to target adolescents for substance use interventions. Addiction 105: 506-14.

Seth P, Cheeta S, Tucci S, File SE (2002) Nicotinic--serotonergic interactions in brain and behaviour. Pharmacology, biochemistry, and behaviour 71: 795-805.

Soiza-Reilly M, Commons KG (2011) Glutamatergic drive of the dorsal raphe nucleus. Journal of chemical neuroanatomy 41: 247-55.

Somm E, Guerardel A, Maouche K, Toulotte A, Veyrat-Durebex C, Rohner-Jeanrenaud F, Maskos U, Huppi PS, Schwitzgebel VM (2014) Concomitant alpha7 and beta2 nicotinic AChR subunit deficiency leads to impaired energy homeostasis and increased physical activity in mice. Molecular genetics and metabolism 112: 64-72.

Sonntag H, Wittchen HU, Hofler M, Kessler RC, Stein MB (2000) Are social fears and DSM-IV social anxiety disorder associated with smoking and nicotine dependence in adolescents and young adults? European psychiatry : the journal of the Association of European Psychiatrists 15: 67-74.

Stevens VL, Bierut LJ, Talbot JT, Wang JC, Sun J, Hinrichs AL, Thun MJ, Goate A, Calle EE (2008) Nicotinic receptor gene variants influence susceptibility to heavy smoking. Cancer epidemiology, biomarkers \& prevention : a publication of the American Association for Cancer Research, cosponsored by the American Society of Preventive Oncology 17: 351725. 
Sudweeks SN, Yakel JL (2000) Functional and molecular characterization of neuronal nicotinic ACh receptors in rat CA1 hippocampal neurons. The Journal of physiology $527 \mathrm{Pt} 3: 515$ 28.

Suto N, Austin JD, Vezina P (2001) Locomotor response to novelty predicts a rat's propensity to self-administer nicotine. Psychopharmacology 158: 175-80.

Taly A, Corringer PJ, Guedin D, Lestage P, Changeux JP (2009) Nicotinic receptors: allosteric transitions and therapeutic targets in the nervous system. Nature reviews Drug discovery 8: 733-50.

Tapia L, Kuryatov A, Lindstrom J (2007) Ca2+ permeability of the (alpha4)3(beta2)2 stoichiometry greatly exceeds that of (alpha4)2(beta2)3 human acetylcholine receptors. Molecular pharmacology 71: 769-76.

Vandermaelen CP, Aghajanian GK (1983) Electrophysiological and pharmacological characterization of serotonergic dorsal raphe neurons recorded extracellularly and intracellularly in rat brain slices. Brain research 289: 109-19.

Wada E, McKinnon D, Heinemann S, Patrick J, Swanson LW (1990) The distribution of mRNA encoded by a new member of the neuronal nicotinic acetylcholine receptor gene family (alpha 5) in the rat central nervous system. Brain research 526: 45-53.

Wang T, Han W, Wang B, Jiang Q, Solberg-Woods LC, Palmer AA, Chen H (2014) Propensity for social interaction predicts nicotine-reinforced behaviours in outbred rats. Genes, brain, and behaviour 13: 202-12.

Ware JJ, van den Bree M, Munafo MR (2012) From men to mice: CHRNA5/CHRNA3, smoking behaviour and disease. Nicotine \& tobacco research : official journal of the Society for Research on Nicotine and Tobacco 14: 1291-9.

Weiss RB, Baker TB, Cannon DS, von Niederhausern A, Dunn DM, Matsunami N, Singh NA, Baird L, Coon H, McMahon WM, Piper ME, Fiore MC, Scholand MB, Connett JE, Kanner RE, Gahring LC, Rogers SW, Hoidal JR, Leppert MF (2008) A candidate gene approach identifies the CHRNA5-A3-B4 region as a risk factor for age-dependent nicotine addiction. PLoS genetics 4: e1000125.

Wong M, Krajisnik A, Truong L, Lisha NE, Trujillo M, Greenberg JB, Kahler CW, Zvolensky MJ, Leventhal AM (2013) Anxiety sensitivity as a predictor of acute subjective effects of smoking. Nicotine \& tobacco research : official journal of the Society for Research on Nicotine and Tobacco 15: 1084-90. 


\section{Figure Legends}

Figure 1: Response to novelty and anxiety-like behaviour in $\alpha 5^{-/-}$mice. $a$, Novelty-induced locomotor activity expressed as total distance travelled in the openfield (left); \% time spent at the periphery of the open-field, in inactivity, in inactivity in the periphery (PI) or center (CI). $\boldsymbol{b}$, Novelty preference in a free-choice procedure expressed as time spent in familiar vs novel environment (left) and \% of novelty preference (right). $\boldsymbol{c}$, Novelty-induced rearing behaviour expressed as number of rearings. $\boldsymbol{d}$, EPM anxiety-related behaviour measured as $\%$ of time spent in open arms (left) and extremities (right). $\boldsymbol{e}$, LDB anxiety-related behaviour expressed as \% of time spent in the light side. Data plotted as mean \pm SEM. Genotype effect: $* p \leq 0.05$, $* * p \leq 0.01$, $* * * p \leq 0.001$. Environment effect for novelty preference: ${ }^{\# \#} p \leq 0.01 . \mathrm{n}=10-12 /$ group.

Figure 2: Effects of nicotine exposure on ${\alpha 5^{-/-}}$mice behavioural phenotypes. $a$, Noveltyinduced rearing behaviour in response to different doses of nicotine, expressed as number of rearings in WT (left) and $\alpha 5^{-/-}$mice (right). $\boldsymbol{b}$, EPM anxiety-related behaviour expressed as $\%$ of time spent in open arms (upper) and in their extremities (bottom) in WT (left) and $\alpha 5^{-/-}$mice (right). $c$, LDB anxiety-related behaviour expressed as $\%$ of time spent in the light side in WT (left) and $\alpha 5^{-/-}$mice (right). Data plotted as mean \pm SEM. Nicotine effect: ${ }^{\#} p \leq 0.05,{ }^{\# \#} p \leq 0.001$ compared to saline. $\mathrm{n}=8-16$ /group.

Figure 3: Effects of nicotine exposure on locomotion in $\alpha 5^{-/-}$mice. $\boldsymbol{a}$, Total distance moved in the EPM in WT (left) and $\alpha 5^{-/-}$mice (right). $\boldsymbol{b}$, Total distance moved (upper); and $\%$ time spent at the periphery, in inactivity, in inactivity in the periphery (PI) or center (CI) in the open-field in WT (left) and $\alpha 5^{-/-}$mice (right). Data plotted as mean \pm SEM. Nicotine effect: ${ }^{\#} p \leq 0.05,{ }^{\# \#} p \leq 0.01$, \#\#\# $p \leq 0.001$ as compared to saline.

Figure 4: Effects of nicotine exposure on DA and 5-HT neurotransmission in WT and $\alpha 5^{-/-}$ mice. $\boldsymbol{a}$, Microdialysis of NAcb DA extracellular levels: Schematic representation of probe location (optimal position and range of accepted positions (dashed lines)) (left); Time course of DA extracellular levels as \% of basal levels after nicotine injection (middle); Area under the curve values (AUC) as \% of basal values for the amount of DA outflow during the 1st hour postinjection (right), n=4-6/group. $\boldsymbol{b}$, DRN 5-HT neurons firing: Basal firing frequency (left), $\mathrm{n}=5$ /group; Number of spontaneous active cells per tract (middle), $\mathrm{n}=11-17$ /group; Changes in firing rate in response to nicotine as $\%$ of basal values, $n=5 /$ group. $c$, Microdialysis of dorsal hippocampus 5-HT extracellular levels: Schematic representation of probe location (optimal 
position and range of accepted positions (dashed lines)) (left); Time course of 5-HT extracellular levels as $\%$ of basal levels after saline and nicotine injection (middle); AUC as \% of basal values for the amount of 5-HT outflow during the 1 st hour post-injection (Right) n=9-10/group. Data plotted as mean \pm SEM. Genotype effect: $* * p \leq 0.01, * * * p \leq 0.001$. Nicotine effect: ${ }^{\#} p \leq 0.05,{ }^{\#} p \leq 0.01$ compared to saline.

Figure 5: Effects the re-expression of WT or polymorphic $\alpha 5$ in the VTA on $\alpha 5^{-/-}$mice behavioural phenotypes. $\boldsymbol{a}$, Scheme of lentiviral vectors (upper); Representative localization of $\mathrm{LV}$ reporter gene eGFP (bottom); examples from $\alpha 5^{-/ \text {GFP }}$ (upper) and $\alpha 5^{-/ \alpha 5 \mathrm{WT}}$ (bottom) mice; zooms from $\alpha 5^{-/-\alpha 5 \mathrm{SNP}}$ mouse (right). Arrowheads point to cells with absence of co-expression. $\boldsymbol{b}$, Number of rearings $\left(W T^{G F P} / \alpha 5^{-/-G F P}: \mathrm{p}=0.001 ; W T^{G F P} / \alpha 5^{-/ \alpha .5 T}: \mathrm{NS} ; \alpha 5^{-/-G F P} / \alpha 5^{-/ \alpha 5 S N P}: \mathrm{NS}\right.$; $\left.W T^{G F P} / \alpha 5^{-\alpha-\alpha S N P}: \mathrm{p}=0.0004 ; \alpha 5^{-/ \alpha 5 W T} / \alpha 5^{-/ \alpha 5 S N P}: \mathrm{p}=0.0009\right) . c$, EPM anxiety-related behaviour: \% of time spent in open arms $\left(W T^{G F P} / \alpha 5^{-/ G F P}: \mathrm{p}=0.008 ; W T^{G F P} / \alpha 5^{-/ \alpha 5 W T}: \mathrm{p}=0.01 ; W T^{G F P} / \alpha 5^{-/ \alpha S S N P}\right.$ : $\mathrm{p}=0.09 ; \alpha 5^{-/-G F P} / \alpha 5^{-/ \alpha 5 W T}: \mathrm{NS} ; \alpha 5^{-/ \alpha 5 W T} / \alpha 5^{-/ \alpha 5 S N P}$ : NS) and their extremities $\left(W T^{G F P} / \alpha 5^{-/ G F P}\right.$ : $\mathrm{p}=0.005 ; W T^{G F P} / \alpha 5^{-/ \alpha 5 \mathrm{WT}}: \mathrm{p}=0.02 ; W T^{G F P} / \alpha 5^{-/ \alpha 5 \mathrm{SNP}}: \mathrm{p}=0.04 ; \alpha 5^{-/-\mathrm{GFP}} / \alpha 5^{-/ \alpha .5 \mathrm{WT}}: \mathrm{NS} ; \alpha 5^{-/ \alpha 5 W T} / \alpha 5^{-/-}$ $\left.{ }^{\alpha 5 S N P}: \mathrm{NS}\right) . \boldsymbol{d}, \mathrm{LDB}$ anxiety-related behaviour: $\%$ of time spent in the light side $\left(W T^{G F P} / \alpha 5^{-/ \mathrm{GFP}}\right.$ : $\mathrm{p}=0.0006 ; W T^{G F P} / \alpha 5^{-/ \alpha 5 \mathrm{WT}}: \mathrm{p}=0.0007 ; W T^{G F P} / \alpha 5^{-/ \alpha .5 S N P}: \mathrm{p}=0.00001 ; \alpha 5^{-/-G F P} / \alpha 5^{-/ \alpha .5 W T}: \mathrm{NS} ; \alpha 5^{-/-}$ ${ }^{\alpha 5 W T} / \alpha 5^{-/ \alpha 5 S N P}$ : NS). Data plotted as mean \pm SEM. Group effect: $* p \leq 0.05, * * p \leq 0.01, * * * p \leq 0.001$. $n=12-20 /$ group.

Figure 6: Effects of the re-expression of WT or polymorphic $\alpha 5$ in the hippocampus on $\alpha 5^{-/-}$ mice behavioural phenotypes. $\boldsymbol{a}$, Representative localization of LV reporter gene eGFP (left); examples from $\alpha 5^{-/-G F P}$ (upper) and $\alpha 5^{-/-\alpha 5 \mathrm{WT}}$ (bottom) mice; zooms from $\alpha 5^{-/-\alpha 5 \mathrm{SNP}}$ mouse (right and bottom). Arrowheads point to cells with absence of co-expression. $\boldsymbol{b}$, Number of rearings $\left(W T^{G F P} / \alpha 5^{-/-G F P}: \mathrm{p}=0.002 ; W T^{G F P} / \alpha 5^{-/ \alpha .5 W T}: \mathrm{p}=0.002 ; W T^{G F P} / \alpha 5^{-/ \alpha S S N P}: \mathrm{p}=0.0007 ; \alpha 5^{-/-G F P} / \alpha 5^{-/ \alpha 5 W T}\right.$ : NS; $\alpha 5^{-/ \alpha 5 W T} / \alpha 5^{-/ \alpha 5 S N P}:$ NS). $c$, EPM anxiety-related behaviour: $\%$ of time spent in open arms $\left(W T^{G F P} / \alpha 5^{-/-G F P}: \quad \mathrm{p}=0.04 ; \quad W T^{G F P} / \alpha 5^{-\alpha-\alpha W T}: \quad \mathrm{NS} ; \alpha 5^{-/-G F P} / \alpha 5^{-/ \alpha 5 W T}: \mathrm{p}=0.07 ; \quad W T^{G F P} / \alpha 5^{-/ \alpha 5 S N P}\right.$ : $\left.\mathrm{p}=0.0002, \alpha 5^{-/ \alpha 5 W T} / \alpha 5^{-/ \alpha 5 S N P}: \mathrm{p}=0.02\right)$ and extremities $\left(W T^{G F P} / \alpha 5^{-/ G F P}: \mathrm{p}=0.02 ; W T^{G F P} / \alpha 5^{-/ \alpha 5 W T}\right.$ : $\left.\mathrm{NS} ; \alpha 5^{-/ G F P} / \alpha 5^{-/ \alpha 5 W T}: \mathrm{p}=0.07 ; W T^{G F P} / \alpha 5^{-/ \alpha 5 S N P}: \mathrm{p}=0.005, \alpha 5^{-/ \alpha 5 W T} / \alpha 5^{-/ \alpha 5 S N P}: \mathrm{p}=0.02\right) . \boldsymbol{d}, \mathrm{LDB}$ anxiety-related behaviour: $\%$ of time spent in the light side $\left(W T^{G F P} / \alpha 5^{-/ G F P}: \mathrm{p}=0.04 ; W T^{G F P} / \alpha 5^{-/-}\right.$ $\left.{ }^{\alpha 5 W T}: \mathrm{NS} ; \alpha 5^{-/ G F P} / \alpha 5^{-/ \alpha 5 W T}: \mathrm{NS} ; W T^{G F P} / \alpha 5^{-/ \alpha 5 S N P}: \mathrm{p}=0.002, \alpha 5^{-\alpha \alpha 5 W T} / \alpha 5^{-/ \alpha .5 S N P}: \mathrm{p}=0.04\right)$. Data plotted as mean \pm SEM. Group effect: ${ }^{*} p \leq 0.05, * * p \leq 0.01, * * * p \leq 0.001 . \mathrm{n}=11-20 /$ group. 